\title{
PRŮKAZ ENERGETICKÉ NÁROČNOSTI BUDOV JAKO NÁSTROJ ENERGETICKÝCH ÚSPOR
}

\author{
LEOŠ KUDLÍK
}

\begin{abstract}
Energy Performance Certificate as an Instrument of Energy Savings
Energy performance certificate is one of the main legal instruments of energy efficiency policy with the objective to reduce energy consumption in buildings in order to meet requirements for the energy performance of buildings. Energy performance certificate shall include the energy performance of a building as well as recommendations for the cost-optimal or costeffective enhancements of the energy performance of a building or building unit. The rating scheme of energy performance certificate also plays a significant role within programmes such as New Green Savings.
\end{abstract}

Keywords: energy performance certificate; energy performance of building; energy savings

Klíčová slova: průkaz energetické náročnosti budov; energetická náročnost budov; energetické úspory

DOI: $10.14712 / 23366478.2020 .2$

\section{1. ÚVODEM}

V oblasti energetiky je snaha o zvyšování energetické účinnosti v současné době prioritou, nebot' energetická účinnost je považována za jedinečný zdroj energie ${ }^{1}$ ve smyslu zásady, že nejlepši a nejekologičtějši je ta energie, kterou vưbec nespotřebujeme. $\mathrm{V}$ tomto článku bych rád průkaz energetické náročnosti budov podrobněji zanalyzoval z pohledu platné právní úpravy. Průkaz energetické náročnosti budov je dokument, který obsahuje informace o energetické náročnosti budovy nebo její ucelené části (dále jako průkaz). Dle mého soudu průkaz představuje důležitý nástroj energetické účinnosti ke snížení spotřeby energie v oblasti budov. ${ }^{2,3}$ Budovy mají významný potenciál ener-

1 Za jedinečný zdroj energie byla energetická účinnost označena např́klad ve Světovém energetickém výhledu 2013 Mezinárodní energetické agentury. Blíže World Energy Outlook 2013. In Iea.org [online]. [cit. 26. 11. 2019]. Dostupné z: http://www.iea.org/publications/freepublications/publication/WEO2013 .pdf.

2 Na národní úrovni došlo k legislativnímu zakotvení požadavků ve vztahu k energetické spotřebě vytápění objektů již v roce 1979. DAHLSVEEN, T. - PETRÁŠ, D. - HIRŠ, J. Energetický audit budov. Bratislava: Jaga group, 2003, s. 36.

3 Energetickou náročností budov se se dle ustanovení § 2 odst. 1 písm. f) zákona o hospodaření energií rozumí „,vypočtené množstvi energie nutné pro pokrytí potřeby energie spojené s užíváním budovy, zejména na 
getických úspor, kdy podle Evropské komise přibližně tři čtvrtiny veškerých obytných budov v Evropské unii nevyhovují požadavkům energetické náročnosti, ${ }^{4}$ přičemž podíl budov na celkové spotřebě energie v Evropské unii tvoří přibližně $40 \%{ }^{5}$ Energetická náročnost budov by měla být komplexně řešena již v počáteční fázi $\mathrm{v}$ rámci tvorby architektonických projektů, kde se tak zohlední konkrétní situace předmětné budovy, především její geografická poloha a místní klimatické podmínky. ${ }^{6}$ Takové posouzení umožní použít vhodná opatření s vyšší účinností. Př́kladem lze uvést budovy, které jsou $\mathrm{z}$ převážné většiny prosklené, např́klad s využitím dvojitých skleněných stěn. Takové budovy nejsou vhodné pro chladnější klima kvůli horšímu izolování a větším tepelným ztrátám. ${ }^{7} \mathrm{~V}$ neposlední řadě je nutné energetická opatření realizovat komplexně s ohledem na veškeré vlastnosti budovy. $V$ prípadě zaměření se pouze na jedinou vlastnost budovy hrozí riziko, že negativa převáží nad přínosy. Nepřiměřené a nevhodné zvýhodnění jediné vlastnosti budovy bez zohlednění ostatních a souvisejících vlastností budovy může být důsledkem nesprávně nastaveného systému poskytování dotací. Za typický projev uvedeného lze považovat zaizolování budov bez vyřešení otázky ventilace, $v$ důsledku čehož pak může docházet $\mathrm{k}$ tvorbě plísní. ${ }^{8}$

\section{PRÁVNÍ ÚPRAVA}

Na unijní úrovni je průkaz upraven Směrnicí Evropského parlamentu a Rady 2010/31/EU ze dne 19. května 2010 o energetické náročnosti budov (dále jako směrnice o energetické náročnosti budov $)^{9}$ ve znění Směrnice Evropského parlamentu a Rady (EU) 2018/844 ze dne 30. května 2018, jakožto změnového předpisu. ${ }^{10}$ Směrnice o energetické náročnosti budov souhrnně upravuje především energetickou náročnost budov a energetické certifikace, včetně ustanovení rámce pro výpočet energetické náročnosti a minimálních požadavků na energetickou náročnost. ${ }^{11}$ Směrnice o energetické

vytápění, chlazení, větrání, úpravu vlhkosti vzduchu, př́pravu teplé vody a osvětleni". Na unijní úrovni je energetická náročnost budov zakotvena v čl. 2 odst. 4 směrnici o energetické náročnosti. Vymezení podle směrnice lze považovat za přesnější, nebot’ legální definice užívá pojmu „typické uživání budovy“ místo „uživání budovy“ dle zákona o hospodaření energií.

4 Energetická unie: bezpečná, udržitelná, konkurenceschopná a cenově dostupná energie pro Evropu [online]. [cit. 30. 11. 2019]. Dostupné z: http://www.consilium.europa.eu/cs/policies/energy-union/.

5 Srov. recitál č. 3 Směrnice Evropského parlamentu a Rady 2010/31/EU ze dne 19. května 2010 o energetické náročnosti budov.

6 Jak je tomu standardně v případě energetického auditu. Více k tomuto viz DAHLSVEEN - PETRÁS̆ HIRŠ, s. 39.

7 KURNITSKI, J. Cost optimal and nearly zero-energy buildings (nzeb). New York, NY: Springer Berlin Heidelberg, 2013, s. 79.

8 Plísně jsou pak mírněny častějším větráním, kterým dochází k tepelným ztrátám.

9 Směrnice Evropského parlamentu a Rady 2010/31/EU ze dne 19. května 2010 o energetické náročnosti budov [online]. [cit. 21. 11. 2019]. Dostupné z: https://eur-lex.europa.eu/legal-content/cs/TXT/?uri =CELEX:32010L0031.

10 Jedná se již o třetí revizi původní Směrnice evropského parlamentu a rady 2002/91/ES ze dne 16. prosince 2002 o energetické náročnosti budov. Česká republika je povinna tuto směrnici implementovat do 10. března 2020.

11 Prostřednictvím této směrnice jsou ukládány administrativněsprávní povinnosti, především pak povinnost informační, a to jak pro soukromé osoby, tak i stát. Blíže k administrativním povinnostem a nástrojům DAMOHORSKÝ, M. Právo životního prostředí. 3. vyd. Praha: C. H. Beck, 2010, s. 176. 
náročnosti dále mimo jiné v čl. 9 zavádí povinnost, aby členské státy zajistily stavbu nových budov v režimu tzv. budov s téměř nulovou spotřebou energie (NZEB, $z$ angl. nearly zero energy building). ${ }^{12}$ Již od 1 . ledna 2019 jsou členské státy povinny zajistit, aby veškeré budovy vlastněné státem byly budovami s téměř nulovou spotřebou energie. ${ }^{13}$ Od 1 . ledna 2020 se povinnost stavět nové budovy v režimu budov s téměr̆ nulovou spotřebou energie vztahuje na veškeré budovy. ${ }^{14}$ Tento požadavek se dokládá prostřednictvím průkazu, který obsahuje hodnocení splnění požadavků na energetickou náročnost budovy s téměř nulovou spotřebou energie. ${ }^{15}$

České znění směrnice o energetické náročnosti terminologicky místo průkazu užívá pojmu certifikát energetické náročnost ${ }^{16}$ (v této souvislosti lze odkázat např́íklad na anglické či francouzské znění směrnice užívající pojmu certificat/e). ${ }^{17}$ České znění směrnice lze považovat do jisté míry za technický překlad, který je však korigován národní legislativou, která užívá pojmu průkaz. Vedle průkazu se nabízí překlad osvědčení, což by dle mého názoru nebylo vhodné, nebot' by pojem osvědčení mohl implikovat, že se jedná o formu správní činnosti ve smyslu části čtvrté zákona č. 500/2004 Sb., správní řád. Pojem průkaz užívaný národní legislativou tak považuji za přiléhavější.

\section{PRŮKAZ A JEHO ZÁKONNÉ VYMEZENÍ}

Na národní úrovni je průkaz zakotven v zákoně č. 458/2000 Sb., o hospodaření energií (dále jako zákon o hospodaření energií). S účinností 1. ledna 2009 byl průkaz zaveden do praxe novelizací zákona o hospodaření energií provedenou zákonem č. 177/2006 Sb. ${ }^{18}$ Průkaz je tak v současné podobě vydáván od 1. dubna 2013 dle novely zákona o hospodaření energií prostřednictvím zákona č. 318/2012 Sb. a vydáním prováděcí vyhlášky č. 78/2013 Sb., o energetické náročnosti budov (dále jako vyhláška o energetické náročnosti budov) ${ }^{19}$ čímž došlo $\mathrm{k}$ implementaci směrnice o energetické náročnosti budov. Podle ustanovení $\S 2$ odst. 1 písm. b) zákona o hospodaření energií se průkazem rozumí „dokument, který obsahuje stanovené informace o energetické náročnosti budovy nebo ucelené části budovy" ${ }^{20}$ Průkaz je tvořen protokolem s popisem

12 Podle směrnice jsou členské státy povinny vypracovat vnitrostátní plány na zvýšení počtu budov s téměř nulovou spotřebou energie. Tato povinnost je provedena ustanovením $\S 11$ odst. 1 písm. b) zákona o hospodaření energií, podle kterého Ministerstvo průmyslu a obchodu zpracovává Národní akční plán energetické účinnosti, jehož součástí jsou Národní akční plán na zvýšení počtu budov s téměř nulovou spotřebou energie a Strategie renovace fondu obytných a komerčních budov v České republice.

13 Tento energetický standard je na národní úrovni upraven zákonem o hospodaření energií a prováděcí vyhláškou č. 78/2013 Sb.

14 Viz ustanovení § 7 odst. 1 písm. c) zákona o hospodaření energií.

15 Podle ustanovení $§ 7$ odst. 1 zákona o hospodaření energií.

16 Viz čl. 2 odst. 12 směrnice o energetické náročnosti budov.

17 Úplné anglické znění je podle ustanovení čl. 2 odst. 12 směrnice energy performance certificate a certificat de performance énergétique.

18 Prováděcím předpisem byla vyhláška č. 148/2007 Sb., o energetické náročnosti budov. Tato vyhláška byla zrušena ke dni 1. dubna 2013.

19 Ve vyhlášce je především konkretizována metodika zpracování, vzor a obsah, včetně podmínek pro jeho umístění.

20 Průkaz je důležité nezaměňovat s energetickým štítkem obálky budovy dle ČSN 73 0540-2 a rovněž s energetickým průkazem budovy dle již zrušené vyhlášky č. 291/2001 Sb., Ministerstva průmyslu a obchodu. 
a posouzením budovy včetně toho, jaká je $\mathrm{v}$ budově spotřeba energií pro provoz budovy za rok, a doporučení pro snížení energetické náročnosti budovy a tzv. systémů technických zařízení budovy. ${ }^{21,22}$ Průkaz dále obsahuje grafickou část $\mathrm{v}$ podobě štítku, ve které je posuzovaná budova podle spotřeby energie a emisí oxidu uhličitého zařazena do jedné ze tříd energetické náročnosti ${ }^{23}$ dle vyhlášky o energetické náročnosti budov tř́ídy A (mimořádně úsporná) až tř́dy $\mathrm{G}$ (mimořádně nehospodárná).

Oprávnění zpracovat průkaz má podle ustanovení § 10 a násl. zákona o hospodaření energií tzv. energetický specialista, tedy osoba vedená v seznamu energetických specialistů. ${ }^{24,25}$ Tuto evidenci je důležité kontrolovat, nebot' pouze taková osoba je oprávněna průkaz vyhotovit. ${ }^{26}$ Vedle energetického specialisty je dále možné zajistit zpracování podle ustanovení § 7a odst. 4 písm. a) bodu 2. „osobou usazenou v jiném členském státě Unie, pokud je oprávněna $k$ výkonu uvedené činnosti podle právních předpisu jiného členského státu Unie“. Povinnost opatřit průkaz je kladena podle ustanovení $\S 7$ a odst. 1 zákona o hospodaření energií na stavebníka, vlastníka budovy či na společenství vlastníků jednotek (dále jako SVJ). ${ }^{27}$ Ten je povinen jej předložit, eventuálně jeho ověřenou kopii, zejména v př́padě nové výstavby, při prodeji či pronájmu budovy, nebo její ucelené části. ${ }^{28,29} \mathrm{U}$ rekonstrukce budov je nutné vyhotovit průkaz, jedná-li se o tzv. větší změnu stavby. V př́padě potřeby stavebního povolení či ohlášení se průkaz přikládá jako př́loha, pokud není již součástí projektové dokumentace. Není-li potřeba ani stavební povolení ani ohlášení, i přesto je třeba průkaz mít vyhotoven, a to již před započetím rekonstrukce. ${ }^{30}$ Výjimky z povinnosti opatřit průkaz jsou stanoveny $\mathrm{v}$ ustanovení § 7a odst. 5 zákona o hospodaření energiií31 a dále pak zvláštní případ podle

Úskalím těchto dokumentů bylo, že hodnotily budovu pouze z hlediska energetické spotřeby tepla na vytápění, což je pouze část bilančního hodnocení. Více k tomuto KABELE, K. Energetická náročnost budov v souvislostech s platnou legislativou $\check{C} R$. Praha: ABF - nakladatelství ARCH, 2008, s. 42.

21 BERNARDINOVÁ, A. - MAREŠ, M. Zpracováni průkazu energetické náročnosti budovy: praktická přriručka pro všechny majitele rodinných a bytových domů, bytů a pro realitni kanceláře. Praha: Linde Praha, 2013, s. 10.

22 Oproti předchozí právní úpravě je hodnotící metodika odlišná. Lze tak mít důvodně za to, že by dle současné metodiky došlo $\mathrm{k}$ zatř́ídění budovy do jiné třídy energetické náročnosti. Hlavním rozdílem je, že současná metodika posuzuje taktéž tvar budovy s cílem přesnějších výpočtů, především pak rozhodné u budov atypických konstrukcí.

23 Obsahem průkazu je taktéž průvodní zpráva věnovaná návrhům opatř̌ení, které mohou přispět k vyšší energetické hospodárnosti budov, včetně nastínění ekonomické návratnosti předmětných opatření.

${ }^{24}$ Seznam energetických specialistů. Mpo-enex.cz [online]. [cit. 4. 12. 2019]. Dostupné z: https://www .mpo-enex.cz/experti/ExpertList.aspx.

25 Výchozím dokumentem pro energetické specialisty je projektová dokumentace, kterou lze nahradit odborným odhadem či energetický specialista může sám na místě vyhotovit údaje, které taktéž mohou projektovou dokumentaci nahradit.

26 V seznamu energetických specialistů lze rozlišovat dle druhu oprávnění, kdy oprávnění může být pro energetický audit, kontrolu klimatizace, kontrolu kotlů a pro energetickou certifikaci budov.

$27 \mathrm{~V}$ príípadě družstevního bytu je povinným bytové družstva podle ustanovení $\S 7 \mathrm{a}$ odst. 2 písm. a) bod 3 zákona o hospodaření energií.

${ }^{28}$ Srov. ustanovení § 7a odst. 2 písm. e) zákona o hospodaření energií.

29 Při prodeji či pronájmu jednotky také vlastník jednotky.

30 BERNARDINOVÁ - MAREŠ, s. 25.

31 Např́klad podle ustanovení $\S 7$ odst. 5 písm. a), c) a d) lze za výjimky považovat budovy s celkovou energeticky vztažnou plochou menší než $50 \mathrm{~m}^{2}$, podle písm. c) budovy navrhované a obvykle užívaných jako místa bohoslužeb a pro náboženské účely či stavby pro rodinnou rekreaci, které jsou uživány jen část roku 
odst. 9 citovaného ustanovení. ${ }^{32}$ Průkaz je platný po dobu 10 let od jeho vyhotovení, platnosti však pozbývá $\mathrm{v}$ situaci, dojde-li $\mathrm{k}$ tzv. větší změně dokončené budovy ${ }^{33}$ nebo změně technického zařízení. ${ }^{34}$

Zákon o hospodaření energií umožňuje za určitých okolností průkaz nahradit vyúčtováním energii. ${ }^{35}$ Průkaz lze nahradit vyúčtováním dodávek elektřiny, plynu a tepelné energie, např́íklad doklad o zaplacení by tedy byl nedostatečný. Pokud takové vyúčtování dodat nelze, typicky z důvodu změny vlastnické struktury, a nový vlastník danou jednotku vlastní méně než 3 roky, vyhotoví průkaz SVJ, nebo vlastník jednotky vyhotoví průkaz na svůj náklad či poskytne vyúčtování pouze za rozhodné období, po které jednotku vlastnil. ${ }^{36}$ Komplikovaná může být situace v príípadě, kdy byt byl pronajímán a smlouva o dodávkách energií byla uzavřena mezi nájemcem a poskytovatelem energií a nájemce odmítne pronajímateli předat vyúčtování. Pokud v takovém př́padě není průkaz vyhotoven pro celou budovu, bude vlastník předmětné jednotky nucen průkaz celé budovy vyhotovit sám.

Na úseku státní správy působí Státní energetická inspekce (dále jako SEI), která dohlíží nad dodržováním povinností vyplývajících ze zákona o hospodaření energií. SEI každoročně kontroluje, zdali jsou průkazy zpracovány objektivně, pravdivě a úplně. ${ }^{37}$ Dále např. průkazy hodnotí během výstavby novostaveb jakožto dotčený orgán státní správy. ${ }^{38}$ SEI také projednává přestupky za nesplnění povinností dle zákona o hospodaření energií ${ }^{39}$ Fyzické osobě lze za přestupek uložit pokutu ve výši až 500000 Kč, podnikající fyzické osobě či právnické osobě lze uložit pokutu ve výši až 5000000 Kč. ${ }^{40}$

\section{PRŮKAZ JAKO INFORMAČNÍ PROSTŘEDEK}

Průkaz lze chápat rovněž jako nosič informací rozhodných pro ochranu životního prostředí. ${ }^{41}$ Průkaz poskytuje informaci o stavu energetické náročnosti budovy, což je výhodné pro obě smluvní strany při disponování s nemovitostí. ${ }^{42}$ Nelze jej

a jejichž odhadovaná spotřeba energie je nižší než 25 \% spotřeby energie, $\mathrm{k}$ níž by došlo při celoročním užívání.

32 POKORNÝ, J. Energie a životní prostředí z právního pohledu. Disertační práce. Praha: Univerzita Karlova, Právnická fakulta, 2017, s. 169.

33 Srov. ustanovení § 2 odst. 1 písm. s) zákona o hospodaření energií.

34 Např. změna způsobu vytápění oproti původní projektové dokumentaci.

35 Uvedené vyplývá zejména z ustanovení § 7a odst. 7 zákona o hospodaření energií.

36 BERNARDINOVÁ - MAREŠ, s. 12.

37 Viz ustanovení § 7a odst. 4 písm. d) zákona o hospodaření energií.

38 Podle ustanovení § 7 zákona o hospodaření energií.

39 Př́islušnost SEI dána ustanovením § $12 \mathrm{~b}$ zákona o hospodaření energií.

40 Viz ustanovení § 12a odst. 2 a 3 zákona o hospodaření energií.

41 Př́stup $\mathrm{k}$ takovým informacím je základní podmínkou pro realizaci účasti veřejnosti na rozhodovacích procesech ve smyslu Úmluvy o př́stupu k informacím, účasti veřejnosti na rozhodování a př́stupu k právní ochraně v záležitostech životního prostředí (Aarhuská úmluva) a čl. 35 odst. 2 Listiny základních práv a svobod.

42 Dílčí složkou této informační povinnosti je mimo jiné povinnost $\mathrm{v}$ inzerátech dané nemovitosti uvádět tř́ídu energetické náročnosti. Nelze-li tuto povinnost splnit, je nutné uvést třídu G. Tímto, však není dotčena povinnost vyhotovení průkazu při prodeji nebo pronájmu nemovitosti. Viz ustanovení § 7a odst. 3 písm. d) zákona o hospodaření energií. 
však považovat za povinnou součást smlouvy. Nepředání průkazu nemá vliv na platnost soukromoprávního jednání, např. smlouva o koupi a prodeji nemovitosti je tak z hlediska soukromého práva platná. Tím však není dotčena rovina veřejnoprávní, tedy riziko sankce podle ustanovení $\S 12$ a násl. zákona o hospodaření energií za nevyhotovení a nepředání průkazu. ${ }^{43}$ Vedle toho by členské státy, co se plnění povinností ve vztahu k průkazu týče, měly jít př́kladem, jak vyplývá z článku 5 Směrnice Evropského parlamentu a Rady 2012/27/EU ze dne 25. rríjna 2012 o energetické účinnosti. ${ }^{44}$

V této souvislosti lze uvést žalobu, kterou na Českou republiku podala Evropská komise $\mathrm{z}$ důvodu nesprávného a nedostatečného zajištění vystavení průkazu u budov užívaných orgány veřejné moci a často navštěvovaných veřejností, které by měly být př́kladem pro zohlednění environmentálních a energetických hledisek. ${ }^{45}$ Podání žaloby předcházelo ř́zení č. 2016/2131 (věc C-305/19) ${ }^{46}$ o nesplnění povinnosti dle článku 258 Smlouvy o fungování EU, ${ }^{47}$ která se týká nesprávné transpozice a následné aplikace některých ustanovení směrnice o energetické náročnosti budov. ${ }^{48}$ Česká republika byla prostřednictvím výzev z roku 2015, 2017 a 2018 upozorněna na rozpor vnitrostátní úpravy s požadavky směrnice o energetické náročnosti budov. Jelikož ani po těchto upozorněních se České republice nepodařilo uvést národní legislativu do souladu s požadavky směrnice, rozhodla se Evropské komise podat žalobu na Českou republiku k Soudnímu dvoru Evropské unie (dále jako SDEU). ${ }^{49}$ Komise nepovažuje za splněnou povinnost, vyplývající z čl. 13. odst. 2 směrnice, tedy že Česká republika nezajistila, aby v budovách, které jsou často navštěvované veřejností, byly průkazy vystaveny. ${ }^{50}$ S ohledem na skutečnost, že se jedná o vadnou, nikoliv opožděnou transpozici, nemůže být $\mathrm{v}$ rámci prvního rozhodnutí SDEU uložena pokuta. Tu může SDEU uložit na návrh Komise, až pokud by ze strany ČR nebylo plněno první odsuzující rozhodnutí. Podle stanoviska Ministerstva průmyslu a obchodu by měla být Česká republika schopna napravit výtky Evropské komise ještě předtím, než by přistoupila k navržení sankcí a SDEU pak k jejich uložení. ${ }^{51} \mathrm{~K}$ nápravě by mělo dojít prostřednictvím novely zákona o hospodaření energií. ${ }^{52}$

43 V praxi časté fiktivní ujednání smluvních stran, že byl průkaz předán, není rozhodné.

44 O změně směrnic 2009/125/ES a 2010/30/EU a o zrušení směrnic 2004/8/ES a 2006/32/ES Text s významem pro EHP.

45 Blíže k tomuto recitál č. 24 směrnice o energetické náročnosti budov.

46 Věc C-505/19 Komise v. Česká republika (Affichage d'un certificat de performance énergetique).

47 Konsolidované znění Smlouvy o fungování Evropské unie [online]. [cit. 4. 12. 2019]. Dostupné z: https:// eur-lex.europa.eu/legal-content/CS/TXT/?uri=celex\%3A12012E\%2FTXT.

48 Nesplnění povinnosti: často kladené otázky [online]. [cit. 4. 12. 2019]. Dostupné z: http://europa.eu/rapid /press-release_MEMO-12-12_cs.htm.

49 Blíže k tomuto tisková zpráva Energetická účinnost budov: Komise postoupila Soudnímu dvoru věc České republiky a Slovinska, protože nezajistily řádné vystavení certifikátů energetické náročnosti v budovách [online]. [cit. 4. 12. 2019]. Dostupné z: http://europa.eu/rapid/press-release_MEMO-19-462_cs.htm.

50 Jak vyplývá z recitálu č. 24 ve vazbě na čl. 3 a 12 směrnice o energetické náročnosti budov, které ovšem hovoří o certifikátech energetické náročnosti, kterými se překladem rozumí právě průkazy energetické náročnosti budov.

51 Stanovisko MPO ČR k rozhodnutí EK podat žalobu na ČR k Soudnímu dvoru EU [online]. [cit. 12. 12. 2019]. Dostupné z: https://www.mpo.cz/cz/rozcestnik/pro-media/tiskove-zpravy/stanovisko -mpo-cr-k-rozhodnuti-ek-podat-zalobu-na-cr-k-soudnimu-dvoru-eu--243251/.

52 Novelizační návrh zákona byl schválen v Poslanecké sněmovně 8 . listopadu 2019 usnesením č. 796. V Senátu byl návrh schválen 11. prosince 2019 usnesením č. 279. Dne 19. prosince 2019 byl návrh zákona 


\section{KULTURNÍ PAMÁTKY, BUDOVY V PAMÁTKOVÉ REZERVACI NEBO PAMÁTKOVÉ ZÓNĚ A HISTORICKÉ BUDOVY}

\section{Výkladové obtíže může činit ustanovení § 7a odst. 5 zákona o hospodaře-}

ní energií ve vazbě na ustanovení $\S 7$ odst. odst. 5 písm. b), a tedy zdali i pro budovy, které jsou kulturní památkou, anebo nejsou kulturní památkou, ale nacházejí se v památkové rezervaci nebo památkové zóně je nutné průkaz vyhotovit. ${ }^{53} \mathrm{U}$ těchto budov je třeba rozlišovat požadavek na energetickou náročnost od samotné povinnosti průkaz zpracovat. Na tyto budovy se nevztahuje požadavek snižovat energetickou náročnost ve smyslu ustanovení $\S 7$ odst. 1 až odst. 3 zákona o hospodaření energií. Podle vyjádření Ministerstva průmyslu a obchodu však tímto není dotčena povinnost zpracovat průkaz i pro tyto budovy. ${ }^{54}$ Toto vyjádření podporuje taktéž energetický specialista Ing. Zdeněk Petrtyl, rozdíl je však oproti jiným budovám takový, že doporučení uvedená v průvodní zprávě průkazu nejsou závazná, pouze však za předpokladu, je-li stanovisko památkového úřadu nesouhlasné. ${ }^{55}$ Historickou budovou ve smyslu ustanovení § 7 odst. 9 zákona o hospodaření energií se rozumí budova, která byla vystavěna a poslední větší změna dokončené budovy na ní byla provedena před 1. lednem 1947. Větší změny zahrnují rekonstrukce, které zasahují do plochy obálky budovy, např. nová okna nebo zateplení fasády či střechy. Jakékoliv vnitřní renovace nemají vliv na výše uvedenou změnu dokončené budovy. $V$ př́padě prodeje či pronájmu takové budovy anebo její ucelené části se průkaz neopatřuje.

\section{PRŮKAZ JAKO PODMÍNKA DOTAČNÍCH PROGRAMU゚}

Energetické posouzení budovy prostřednictvím průkazu je jedna z hlavních podmínek pro získání dotací, kterými se realizují energeticky úsporná opatření. Stát se těmito programy, které jsou převážně hrazené z unijních prostředků, snaží přispět k motivaci pořizování energeticky úsporných opatření. ${ }^{56}$ Úskalím získání prostředků z těchto programů je vysoká administrativní náročnost a nevhodně nastavené podmínky. ${ }^{57}$ Jako př́íklad lze uvést dotační program „Nová zelená úsporám“ .58 Cílem tohoto

podepsán prezidentem a následujícího dne byl schválený zákon odeslán k publikaci ve Sbírce listin. Novela vejde v platnost 15 dní po zveřejnění ve Sbírce zákonů ČR.

53 Jedná se o instituty podle zákona č. 20/1987 Sb., o státní památkové péči.

54 Často kladené dotazy a odpovědi k zákonu č. 406/2000 Sb., o hospodaření energií a k prováděcím vyhláškám. Mpo.cz [online]. [cit. 6. 6. 2019]. Bod č. 26. Dostupné z: https://www.mpo.cz/assets/dokumenty /48052/54907/601903/priloha001.pdf.

55 Vyjádření pana Ing. Petrtyla dostupné zde: Průkaz energetické náročnosti budovy (PENB) - kulturní památka. In Inkapo.cz [online]. [cit. 9. 6. 2019]. Dostupné z: http://www.inkapo.cz/dotaz/prukaz-energeticke -narocnosti-budovy-penb-prodej-kulturni-pamatka?page $=3$.

56 Tyto dotace mají právní základ v Nařízení Evropského parlamentu a Rady (EU) č. 1303/2013. Evropská unie podporuje energeticky úsporná opatření prostřednictvím strukturálních fondů, na jejichž základě jsou poskytovány dotace na úrovni členských států. Srov. POKORNÝ, s. 227.

57 Problémem může být, že dotační program je zaměřen pouze na jeden aspekt či jednu vlastnost. Takto např. dotační programy zaměřené pouze na zateplení objektů nezohlednily aspekt větrání či ventilace.

58 Dále pak např́klad Operační program Podnikání a inovace a konkurenceschopnost, Operační program Životní prostředí. 
programu je podpora energetických úspor v rámci rekonstrukcí bytových jednotek a rodinných domů.

V této souvislosti lze zmínit významný ekonomický nástroj, Evropský systém obchodování s emisními povolenkami (tzv. EU ETS, z anglického EU Emission Trading System) ${ }^{59}$ a související novelu zákona č. 383/2012 Sb., o podmínkách obchodování s povolenkami na emise skleníkových plynů (dále jako zákon o podmínkách obchodování s povolenkami na emise skleníkových plynů). ${ }^{60,61}$ Tato novela reflektuje revizi směrnice 2003/87/ES zavádějící Evropský systém obchodování s povolenkami (dále jako směrnice EU ETS), provedenou směrnicí Evropského parlamentu a Rady (EU) 2018/410 ze dne 14. března 2018. ${ }^{62}$ Evropská unie zavádí pro deset členských států s nižším HDP, včetně České republiky, tzv. Modernizační fond, kdy část finančních prostředků bude přidělena České republice za účelem podpory projektů na snižování emisí skleníkových plynů, využití obnovitelných zdrojů energie a zvyšování energetické účinnosti. ${ }^{63}$ Tento fond bude $\mathrm{v}$ rámci České republiky fungovat obdobně jako dotační programy prostřednictvím výzev, přičemž jednotlivé projekty bude nutné zaslat k finálnímu schválení Evropské investiční bance. ${ }^{64}$ Předpokládaný objem prostředků by v tomto fondu v období let 2021 až 2030 měl být okolo 100 miliard korun. ${ }^{65}$ Jako pozitivní změnu lze vnímat nejen zřízení tohoto fondu, ale i záměr směřovat výnosy z aukcí povolenek do energeticky úsporných opatření s cílem podpory projektů na snižování emisí skleníkových plynů, využití obnovitelných zdrojů energie a zvyšování energetické účinnosti.

\section{ZÁVĚREM}

Průkaz je předním nástrojem snižování energetické náročnosti budov jakožto oblasti s vysokým potenciálem energetických úspor. Energetickou náročnost budov je nutné řešit komplexně s ohledem na veškeré vlastnosti budovy a podmínky, ve kterých se nachází. Průkaz je důležitý informační nástroj, prostřednictvím kterého dochází k poskytnutí údajů o stavu energetické náročnosti budovy. Součástí průkazu jsou doporučení pro snížení energetické náročnosti budovy, rovněž i zařazení do třídy energetické náročnosti A až G, přičemž nejvíce úsporná je tř́ída A. Členské státy by měly plnit př́kladnou roli, co se plnění povinností ve vztahu k průkazu týče, především pak zajištění řádného vystavení průkazu v budovách, které jsou užívané orgánem veřejné moci a určené k uživání veřejností. Jelikož se České republice nepodařilo tomuto závazku

\footnotetext{
59 Jako projev zásady znečištovatel platí v jejím širším pojetí.

${ }^{60}$ Ekonomický nástroj obchodování s emisními povolenkami spočívá v oprávnění soukromé osoby $\mathrm{k}$ vypouštění určitého množství znečištujících látek. Tato oprávnění lze v rámci trhu prodávat, což přispívá k motivaci šetrnější výroby. Blíže k tomuto DAMOHORSKÝ, s. 180-181.

61 Na systém EU ETS je navázán fond NER 300, s cílem finančně podporovat rozvoj šetrných technologií ve vztahu k zachycování a ukládání $\mathrm{CO}_{2}$. Blíže k tomuto POKORNÝ, s. 227.

62 Od 1. ledna 2021 nastává již čtvrté obchodovací období.

63 VRBOVÁ, Z. Novela zákona o emisních povolenkách: další šance pro klimatickou politiku české republiky? Acta Universitatis Carolinae Iuridica, 2019, roč. LXV, č. 3, s. 75-83.

${ }^{64}$ Podle bodu 16 směrnice Evropského parlamentu a Rady (EU) 2018/410 ze dne 14. března 2018, kterou se mění směrnice 2003/87/ES.

65 V závislosti na ceně emisních povolenek.
} 
dostát, Evropská komise podala z důvodu nesprávné transpozice směrnice o energetické náročnosti budov na Českou republiku žalobu $\mathrm{k}$ SDEU. K nápravě by mělo dojít prostřednictvím novely zákona o hospodaření energií, provedené zákonem č. 3/2020 Sb., s účinností od 25. ledna 2020. Energetické posouzení budovy prostřednictvím průkazu je taktéž jednou z hlavních podmínek dotačních programů, které jsou převážně hrazeny $\mathrm{z}$ unijních prostředků, mimo jiné z výnosů emisních povolenek. Za pozitivní vývoj lze považovat prioritu směřovat část $\mathrm{z}$ těchto výnosů do energeticky úsporných opatření. De lege ferenda lze očekávat posilování role průkazu ve vztahu k naplňování cílů zvyšování energetické účinnosti jako jednoho z hlavních nástrojů zvyšování energetických úspor.

Mgr. Leoš Kudlík

leoskudlik@gmail.com 